\title{
HUBUNGAN POLA ASUH ORANGTUA DENGAN MOTIVASI BELAJAR SISWA KELAS VIII DI SMP BAHRUL ULUM KOTA BOGOR
}

\author{
Desi Permatasari ${ }^{1}$, Dr Chodidjah Makarim, M.Si ${ }^{2}$ \\ Universitas Ibn Khaldun Bogor
}

\begin{abstract}
In the learning process, motivation is needed, because someone who does not have motivation to learn will not be able to carry out learning activities. In shaping learning motivation, parents play an important role in parenting their children. Parenting patterns play an important role in the success of an education. Therefore, this study aims to determine how parenting styles with the learning motivation of grade VIII students at SMP Bahrul Ulum Bogor City. This study uses a quantitative approach. The data collection technique used in this study was a questionnaire. The subjects of this study were students of class VIII at SMP Bahrul Ulum Bogor, totaling 24 students. The data analysis technique used in this study was to use SPSS 22 for Windows.
\end{abstract}

Based on the results of the analysis above, it can be concluded that the correlation value of the $X$ and $Y$ variables is 0.755 , when viewed from the interpretation table the value obtained is 0.755 which lies between 0.70 - 0.90. Judging from the data interpretation, including strong correlation. Then by looking at the table value on " $r$ " with a significance value obtained " $r$ " table of 0.432. Thus at the 5\% significance level $" r$ " count $=0.755>$ from the " $r$ " table $=0.432$, it means that the alternative hypothesis $(\mathrm{Ha})$ is accepted and $(\mathrm{Ho})$ is rejected. So there is a significant relationship between parenting styles and learning motivation of grade VIII students at SMP Bahrul Ulum, Bogor City.

Keywords: Parenting Patterns, Learning Motivation

\section{PENDAHULUAN}

Motivasi adalah suatu perubahan energi di dalam pribadi seseorang yang ditandai dengan timbulnya afektif (perasaan) dan reaksi untuk mencapai tujuan. Perubahan energi dalam diri seseorang itu berbentuk semua aktivitas nyata berupa kegiatan fisik,. Karena seseorang mempunyai tujuan tertentu dari aktivitasnya, maka seseorang mempunyai motivasi yang kuat untuk mencapainya dengan segala upaya yang dapat dia lakukan untuk mencapainya. (Djamarah, 2011, hal. 148)

Motivasi (motivation) melibatkan proses yang memberikan energi, mengarahkan, dan mempertahankan perilaku. Dengan demikian, perilaku yang termotivasi adalah perilaku yang mengandung energi, memiliki arah, dan dapat dipertahankan. (W. Santrock, 2011, hal.199)

Menurut Maslow, sangat percaya bahwa tingkah laku manusia dibangkitkan dan diarahkan oleh kebutuhan-kebutuhan tertentu, seperti kebutuhan fisiologis, rasa aman, 
rasa cinta, penghargaan, aktualisasi diri, mengetahui dan mengerti, dan kebutuhan estetik. Kebutuhan-kebutuhan inilah menurut Maslow yang mampu memotivasi tingkah laku individu. (Djamarah, 2011, hal. 149) Jadi, motivasi belajar adalah kondisi psikologis yang mendorong seseorang untuk belajar.

Banyak orang tua masa kini yang lebih mementingkan bekerja untuk mendapatkan uang banyak tanpa memberikan perhatian yang lebih kepada anak-anaknya, sehingga anak kurang terkontrol dalam masalah pergaulan dan belajarnya. Hubungan dekat antara orang tua dan anak sangat diperlukan sekali. Jika orang tua yang jarang memperhatikan perkembangan belajar anak, orang tua yang kurang mengerti tentang apa saja yang dibutuhkan untuk menunjang keberhasilan anak, atau orang tua yang jarang menemani, membimbing dan memberi semangat belajar anak sehingga motivasi belajar anak menjadi rendah. Keberhasilan anak dalam pendidikan itu sangat diharapkan oleh setiap orang tua, untuk itu orang tua harus lebih menyesuaikan diri dengan anaknya dan memperhatikan perkembangan anak.

Dengan peranan pentingnya motivasi dalam belajar, terdapat pula peranan orang tua dibelakangnya yang turut penting dalam menumbuhkan motivasi belajar siswa. Pola asuh orang tua memegang peranan yang sangat penting dalam berbagai hal, salah satunya proses belajar. Proses belajar dapat terbentuk dengan adanya motivasi. Orang tua dapat menjadi faktor pemicu meningkatnya motivasi belajar anak.

Pola asuh adalah cara atau model orang tua dalam membimbing dan mendidik anak dalam lingkungan asuhannya dan mampu menciptakan suatu kondisi yang harmonis dalam lingkungan keluarga dan masyarakat. (Amin, 2018, hal. 2) Pola asuh orang tua adalah cara yang sudah menjadi kebiasaan yang diterapkan oleh orang tua yaitu ayah dan ibu dalam mengasuh, membimbing dan mendidik anak-anaknya. Jadi yang dimaksud dengan pola asuh orang tua adalah pola yang diberikan orang tua dalam mendidik atau mengasuh anak baik secara langsung maupun tidak langsung. Cara mendidik secara langsung artinya bentuk asuhan orang tua yang berkaitan dengan pembentukan kepribadian, kecerdasan, dan ketrampilan yang dilakukan secara sengaja, baik berupa perintah, larangan, hukuman, penciptaan situasi maupun pemberian hadiah sebagai alat pendidikan, sedangkan mendidik secara tidak langsung merupakan contoh kehidupan sehari-hari mulai dari tutur kata sampai kepada adat kebiasaan, dan pola hidup.

Dalam pengasuhan anak, anak akan memperoleh perkembangan yang sangat baik apabila pola asuh yang diterapkan sesuai dengan kebutuhan dan kondisi dari setiap individu anak. Oleh karena itu, orang tua harus lebih teliti dalam menyikapi perannya kepada anak dan harus menerapkan pola asuh yang baik dalam mengasuh anaknya karena seorang anak adalah aset yang harus dijaga dan dibimbing agar kelak menjadi anak yang bersyaksiyah Islam (pola fikir dan pola sikap Islam) dan dapat bermanfaat bagi bangsa dan agama. 


\section{METODE PENELITIAN}

Pendekatan yang digunakan dalam penelitian ini adalah pendekatan kuantitatif. Penelitian kuantitatif adalah suatu proses menemukan pengetahuan yang menggunakan data berupa angka sebagai alat menganalisis keterangan mengenai apa yang ingin diketahui. (Sujarweni, 2019, hal. 39)

Penelitian pada umumnya dilakukan pada populasi atau sampel tertentu yang representatif. Proses penelitian bersifat deduktif, di mana untuk menjawab rumusan masalah digunakan konsep atau teori sehingga dapat dirumuskan hipotesis. Hipotesis tersebut selanjutnya diuji melalui pngumpulan data lapangan. Untuk mengumpulkan data digunakan instrument penelitian. Data yang teekumpul selanjutnya dianalisis secara kuantitatif dengan menggunakan statistik deskripif atau inferensial sehingga dapat disimpulkan hipotesis yang dirumuskan terbukti atau tidak. Penelitian kuantitatif pada umumnya dilakukan pada sampel yang diambil secara random, sehingga kesimpulan hasil penelitian dapat digenaralisasikan pada populasi di mana sampel tersebut diambil. Dalam metode penelitian ini akan di uraikan tempat dan waktu penelitian, definisi operasional, variabel penelitian, populasi, sampel dan teknik pengambilan sampel, teknik pengumpulan data, seta teknik analisis data Metode yang digunakan dalam penelitian ini adalah metode kuantitatif.

Sedangkan untuk mengambil data, peneliti menggunakan wawancara. Wawancara adalah situasi peran antar pribadi bertemu muka (face-to-face), ketika seseorang "yakni pewawancara" mengajukan pertanyaan-pertanyaan yang dirancang untuk memperoleh jawaban-jawaban yang relevan dengan masalah penelitian, kepada seseorang yang diwawancara, atau responden. (Winarno, 2013, hal. 105) Menurut Sugiyono, wawancara tidak terstruktur adalah wawancara yang bebas dimana penulis tidak menggunakan pedoman wawancara yang telah tersusun secara sistematis dan lengkap untuk pengumpulan datanya. Pedoman wawancara yang digunakan hanya berupa garis-garis besar permasalahn yang akan ditanyakan. (Sugiyono, 2018, hal. 140) Wawancara yang dilakukan yaitu wawancara tidak terstruktur.

Selain dengan menggunakan teknik wawancara, peneliti juga menggunakan teknik pengambilan angket atau kuesioner. Kuesioner merupakan teknik pengumpulan data yang dialakukan dengan cara memberi seperangkat pertanyaan atau pernyataan tertulis kepada responden untuk dijawabnya. Kuesioner merupakan teknik pengumpulan data yang efisien bila peneliti tahu dengan pasti variabel yang akan diukur dan tahu apa yang bisa diharapkan dari responden. (Sugiyono, 2018, hal. 142)

Dengan demikian jumlah sampel yang diambil hanya pada siswa kelas VIII di SMP Bahrul Ulum Kota Bogor tahun pelajaran 2020/2021 yang berjumlah 24 siswa dari keseluruhan responden yang berjumlah 40 orang siswa.

Tahap selanjutnya setelah seluruh responden menjawab pertanyaan dari angket tersebut adalah menganalisis data. Analisis data menggunakan Koefisien Korelasi Uji Product Moment. Hasil penelitian yang di dapat dengan uji tabel $r$ hitung, setelah itu 
berkonsultasi dengan tabel r. Data yang dianalisis adalah data hasil angket pola asuh orang tua dengan motivasi belajar siswa.

\section{KAJIAN TEORI}

Penelitian ini dilakukan untuk mengetahui sejauh mana Hubungan Pola Asuh orangtua dengan Motivasi Belajar siswa kelas VIII di SMP Bahrul Ulum Kota Bogor. Pada bagian penelitian ini penulis mengumpulkan sejumlah data-data mengenai tentang sekolah dari tata usaha sekolah dan bersumber dari murid-murid SMP Bahrul Ulum Kota Bogor. Selanjutnya penelitian ini juga untuk mengetahui Pola Asuh orangtua, faktorfaktor yang mempengaruhi Pola Asuh orangtua, Motivasi Belajar dan faktor-faktor yang mempengaruhi Motivasi Belajar siswa. Pada sisi ini penulis melakukan penyebaran Kuesioner secara langsung kepada siswa dan siswi SMP Bahrul Ulum Kota Bogor.

Sebelum pembahasan lebih jauh penulis ingin memberitahu hakekat Pola Asuh Orangtua. Seperti yang telah kita tahu bahwa mendidik dan menbimbing anak merupakan suatu kewajiban bagi setiap orang tua karena anak merupakan amanah yang harus dipertanggung jawabkan kelak kepada Sang khalik. Orang tua harus mampu menerapkan pendidikan yang membuat anaknya mempunyai prinsip untuk menjalankan hidupnya dengan positif, baik dari agama, pergaulan maupun lingkungan, sehingga mampu membentuk mereka menjadi anak yang mempunyai akhlakul karimah, menunjukkan hal yang bermanfaat dan menjadi generasi unggul.

Di Indonesia istilah yang maknanya mendekati parenting adalah pengasuhan. Dalam Kamus Bahasa Indonesia (2008) pengasuhan berarti hal (cara, perbuatan, dan sebagainya) mengasuh. Istilah asuh sering dirangkaikan dengan asah dan asih menjadi asah-asih-asuh. Mengasah berarti melatih agar memiliki kemampuan atau kemampuannya meningkat. Mengasihi berarti mencintai dan menyayangi. Dengan rangkaian kata asah-asih-asuh, maka pengasuhan anak bertujuan untuk meningkatkan atau mengembangkan kemampuan anak dan dilakukan dengan dilandasi rasa kasih sayang tanpa pamrih. (Lestari, 2014, hal. 36-37)

Menurut Ahmad Tafsir pola asuh berarti pendidikan. Dengan demikian, pola asuh orang tua adalah upaya orang tua yang konsisten dan persisten dalam menjaga dan membimbing anak dari sejak dilahirkan hingga remaja. Pola asuh orang tua adalah pola perilaku yang diterapkan pada anak dan bersifat relatif konsisten dari waktu ke waktu. (Bahri, 2014, hal. 53)

Pola asuh adalah cara atau model orang tua dalam membimbing dan mendidik anak dalam lingkungan asuhannya dan mampu menciptakan suatu kondisi yang harmonis dalam lingkungan keluarga dan masyarakat. (Amin, 2018, hal. 2)

Dari beberapa pengertian diatas penulis menyimpulkan bahwa pola asuh orang tua adalah cara yang sudah menjadi kebiasaan yang diterapkan oleh orang tua yaitu ayah dan ibu dalam mengasuh, membimbing dan mendidik anak-anaknya. Jadi yang dimaksud dengan pola asuh orang tua adalah pola yang diberikan orang tua dalam mendidik atau 
mengasuh anak baik secara langsung maupun tidak langsung. Cara mendidik secara langsung artinya bentuk asuhan orang tua yang berkaitan dengan pembentukan kepribadian, kecerdasan, dan keterampilan yang dilakukan secara sengaja, baik berupa perintah, larangan, hukuman, penciptaan situasi maupun pemberian hadiah sebagai alat pendidikan, sedangkan mendidik secara tidak langsung merupakan contoh kehidupan sehari-hari mulai dari tutur kata sampai kepada adat kebiasaan, dan pola hidup.

Pola asuh orang tua dalam keluarga berarti kebiasaan orangtua, ayah dan ibu, dalam memimpin, mengasuh dan membimbing anak dalam keluarga. Mengasuh dalam arti menjaga dengan cara merawat dan mendidiknya. Membimbing dengan cara membantu, melatih dan sebagainya. Keluarga adalah sebuah institusi keluarga batih yang disebut nuclear family. Menurut Ahmad Tafsir pola asuh berarti pendidikan. Dengan demikian, pola asuh orangtua adalah upaya orangtua yang konsisten dan persisten dalam menjaga dan membimbing anak dari sejak dilahirkan hingga remaja. Pola asuh orangtua adalah pola prilaku yang diterapkan pada anak dan bersifat relatif konsisten dari waktu ke waktu. Pola prilaku ini dapat dirasakan oleh anak dan bisa memberi efek negatif dan positif. Orang tua memiliki cara dan pola tersendiri dalam mengasuh dan membimbing anak.(Djamarah S. B., 2014 , hal. 51)

Ada 3 macam tipe pola asuh orangtua yaitu sebagai berikut: (a) Pola asuh otoriter : Tipe pola asuh otoriter adalah tipe pola asuh orangtua yang memaksakan kehendak. Dengan tipe orangtua ini cenderung sebagai pengendali dan pengawas, selalu memaksa kehendak kepada anak, tidak terbuka terhadap pendapat anak, sangat sulit menerima saran dan cenderung memaksakan kehendak dalam perbedaan, terlalu percaya kepada diri sendiri sehingga menutup katup musyawarah. Dalam upaya mempengaruhi anak sering mempergunakan pendekatan yang mengandung unsur paksaan dan ancaman. Kata kata yang diucapkan orangtua adalah hukum atau peraturan dan tidak dapat dirubah, memonopili tindakan komunikasi dan sering kali meniadakan umpan balik dari anak. Hubungan antar pribadi diantara orangtua dan anak cenderung renggang dan berpotensi antagonistik (berlawanan). Pola asuh ini sangat cocok untuk anak paud dan tk dan masih bisa digunakan untuk anak sd dalam kasus-kasus tertentu. (Bahri, 2014, hal. 60) (b) Pola asuh Demokratis : Pengasuhan Othotitatif (Demokratis) adalah tipe yang mendorong untuk mandiri, namun masih menempatkan batas dan kendali pada tindakan mereka. (Santrok, 2011: hal. 167) Beberapa ciri dari tipe pola asuh demokratis adalah sebagai berikut: 1) Dalam proses pendidikan terhadap anak selalu bertitik tolak dari pendapat bahwa manusia itu adalah makhluk yang termulia di dunia. 2) Orang tua selalu berusaha menyelaraskan kepentingan dan tujuan pribadi dengan kepentingan anak. 3) Orang tua senang menerima saran, pendapat, dan bahkan kritik dari anak. 4) Mentolerir ketika anak membuat kesalahan dan memberikan pendidikan kepada anak agar jangan berbuat kesalahan dengan tidak mengurangi daya kreativitas, inisiatif dan prakarsa dari anak. 5) Lebih menitikberatkan kerja sama dalam mencapai tujuan. Orang tua selalu berusaha untuk menjadikan anak lebih sukses darinya. (c) Pola Asuh Permisif : Pengasuhan 
Permissive adalah tipe pengasuhan dimana orang tua sangat terlibat dengan anak, namun tidak terlalu menuntut atau mengontrol mereka. (Santrock, 2011, hal. 167) Selain itu orang tua tidak pernah memberikan hukuman dan menegakkan aturan secara ketat, dan cenderung untuk mengacuhkan dan memaafkan tingkah laku bermasalah. Orang tua lebih banyak memberikan kebebasan pada anak dengan menerima dan memaklumi segala perilaku, tuntutan, dan tindakan anak, namun kurang menuntut sikap tanggung jawab dan keteraturan perilaku anak. Orang tua yang demikian akan berperan sebagai sumber daya pemenuhan segala kebutuhan anak. Orang tua akan menuruti semua keinginan anak tanpa mempertimbangkannya. Sehingga anak tidak akan memiliki sikap kemandirian pada dirinya. (Aenun, 2017, hal. 25) Menurut Suci Amin (Amin, 2018, hal. 2-13) terdapat ciriciri sikap yang diterapkan pola asuh permisif, yaitu: 1) Orangtua tidak menegur atau tidak memperingatkan anak dan sangat sedikit bimbingan yang diberikan orangtua. 2) Orangtua memberikan kebebasan keoada anak untuk menyatakan dorongan atau keinginannya. 3) Orangtua tidak pernah menegur atau tidak berani menegur perilaku anak, meskipun perilaku tersebut sudah keterlaluan atau diluar batas kewajaran. Orangtua yang menerapkan pola asuh permisif cenderung memberikan kebebasan penuh pada anak tanpa adanya aturan ataupun yang ditunjukkan oleh anak, tidak diberikannya hadiah maupun pujian ketika anak memperlihatkan perilaku yang baik dalam lingkungan sosialnya serta tidak diberikan hukuman ketika melakukan kesalahan dalam berperilaku dilingkungan sosialnya.

Al Hasan az-Zhecolany telah berhasil membutiri berbagai macam bentuk kesalahan orang tua dalam mendidik anak. Pemikirannya itu terhimpun dalam bukunya KesalahanKesalahan Orang Tua Yang Menyebabkan Anak Tidak Shaleh, terbitan 2011, halaman 65-111. Jika dibutiri lebih jauh, kesalahan pola asuh orang tua berikut ini, yaitu: 1) Ketidaksamaan dalam menyikapi perilaku anak. 2) Selalu menuruti keinginan anak. 3) Kesalahan menempatkan kasih sayang. 4) Miskin sopan santun dalam bahasa dan perilaku. 5) Pengawasan yang berlebihan terhadap anak. 6) Penerapan norma keluarga yang terlalu ketat. 7) Kesalahan mentradisikan budaya, norma, dan nilai. 8) Deskriminatif dalam menyikapi prestasi belajar anak. 9) Deskriminatif dalam memperlakukan anak. 10) Terlalu berlebihan dalam memberi kebebasan kepada anak. 11) Pencitraan yang keliru terhadap perkembangan anak. 12) Miskin keteladanan, kebiasaan yang baik, dan budaya malu. 13) Miskin keteladanan budaya silaturahmi. 14) Miskin keakraban dengan anak. 15) Miskin budaya membaca dan penghargaan. (Bahri, 2014:69-71)

\section{Faktor Yang Mempengaruhi Pola Asuh}

Ada beberapa faktor yang mempengaruhi pola asuh orang tua terhadap anak, antara lain: (a) Status ekonomi keluarga: Status ekonomi keluarga merupakan salah satu faktor yang mempengaruhi pola asuh yang diterapkan orang tua. Status ekonomi keluarga mencakup penghasilan, pendidikan dan pekerjaan orang tua. Seseorang yang mempunyai status ekonomi rendah kemungkinan besar akan lebih mengutamakan dirinya untuk bekerja, baik itu ayah ataupun ibu. Orang tua yang bekerja akan menghabiskan sebagian 
waktunya jauh dari anak karena mereka lebih mengutamakan atau mementingkan tugas utamanya yaitu bekerja. (Aenun, N, 2017, hal. 27) Orang tua yang lebih banyak menghabiskan waktuya diluar rumah, tidak akan mampu mangamati proses-proses perkembangan anaknya baik dari segi kognitif, afektif, maupun psikomotoriknya. Selain itu, status ekonomi keluarga juga akan mempengaruhi proses belajar siswa. Hasil belajar yang baik, tidak hanya mengandalkan dari keterangan-keterangan yang dijelaskan oleh guru tetapi juga alat-alat belajar yang memadai. Namun, apabila ekonomi keluarga kurang memadai tentunya kebutuhan tersebut tidak dapat dipenuhi. (Aenun, N, 2017, hal. 27-28) Selain itu, orang tua yang memiliki ekonomi menengah akan berbeda dengan orang tua yang memiliki ekonomi yang rendah baik dari segi gizi makanan, perawatan kesehatan, dan pendidikan. Robert E. Slavin mengatakan bahwa "Banyak anak dari keluarga yang berpenghasilan rendah memperoleh pengasuhan yang kurang sesuai dengan apa yang diharapkan untuk mereka lakukan di sekolah dibandingkan dengan pengasuhan anakanak kelas menengah. (Aenun, N, 2017, hal. 28) b) Status pendidikan: Pendidikan yang ditempuh oleh orang tua anak berbeda-beda, maka tak heran apabila pendidikan yang diterima oleh anak pun berbeda. Menurut Halle, "Ibu-ibu yang pendidikan tinggi memiliki harapan yang lebih tinggi terhadap prestasi pendidikan akademik anak-anak mereka".

Orang tua yang memiliki pendidikan yang tinggi menginginkan anaknya memperoleh pendidikan yang sama seperti orang tua nya bahkan ada pula yang menginginkan lebih dari pendidikan orang tua nya. (Aenun, N, 2017:28) Pendidikan dan pengalaman orang tua dalam perawatan anak memengaruhi persiapan mereka menjalankan pengasuhan. Ada beberapa cara yang dapat dilakukan untuk menjadi lebih siap dalam menjalankan peran pengasuhan, antara lain terlibat aktif dalam setiap pendidikan anak, mengamati segala sesuatu dengan berorientasi pada masalah anak, selalu berupaya menyediakan waktu untuk anak-anak dan menilai perkembangan fungsi keluarga dan kepercayaan anak. (Amin, 2018, hal. 13) c) Budaya/adat pola asuh orang tua terdahulu: Dalam mengasuh anaknya kebanyakan orang tua menerapkan sistem budaya/adat ibu-bapak mereka dulu. Andyda Meliala yang mengatakan "Tanpa ada kesadaran untuk mempelajari pengasuhan anak, kita akan menjadi orang tua yang secara otomatis mengulangi cara pengasuhan orang tua kita”. Pernyataan tersebut menunjukkan bahwa orang tua kita kebanyakan menerapkan pola asuh yang diterapkan orang tuanya dahulu. (Aenun, N, 2017, hal. 28-29) Pada zaman terdahulu kebanyakan orang tua menerapkan pola asuh otoriter yaitu pola asuh yang lebih menekankan pada aturan dan hukuman, tak salah jika orang tua zaman sekarang masih menerapkan pola asuh tersebut. Namun ada beberapa orang tua yang meniggalkan pola asuh orang tua mereka, karena mereka menginginkan anaknya memiliki perkembangan yang jauh lebih baik bagi perkembangannya bagi dalam segi kecerdasan, emosi, atau sosialnya. (Aenun, N, 2017, hal. 29) 
Pola asuh orang tua dalam perspektif islam

Rasulullah SAW bersabda:

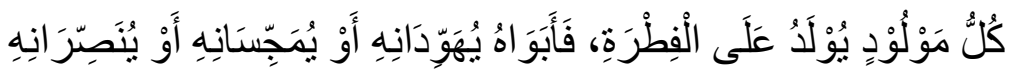

"Setiap anak yang lahir dilahirkan di atas fitrah, maka kedua orang tuanya lah yang menjadikannya Yahudi, Majusi, atau Nasrani." (H.R Bukhori)

Hal itu dikarenakannya begitu pentingnya pengajaran orang tua kepada anak-anak. Orang tua merupakan teladan yang dijadikan teladan anak-anak. Adapun anak-anak belajar dari orang tuanya.

Orangtua mendidik anak-anak bukan untuk tujuan dunia saja, tetapi menyiapkan mereka untuk kehidupan akhirat yang didalamnya terdapat kekekalan dan kebahagiaan yang abadi bagi mereka.

Adapun dijelaskan dalam Al-Qur'an pada Q.S At-Tahrim: 6

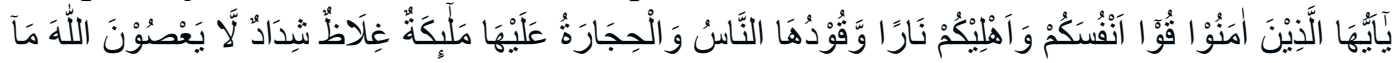

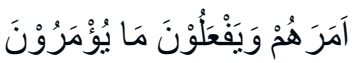

Artinya: "Hai orang-orang yang beriman, peliharalah dirimu dan keluargamu dari api neraka yang bahan bakarnya adalah manusia dan batu, penjaga maliakat-malaikat yang kasar, keras, dan tidak mendurhakai Allah terhadap apa yang diperintah-Nya kepada mereka dan selalu mengerjakan apa yang diperintahkan."

Tulisan ini akan mendeskripsikan satu persatu dari lima perkara metode dan sarana yang berpengaruh pada anak dari konsep Abdullah Nasih Ulwan, yaitu: 1) Mendidik dengan keteladanan. Keteladanan dalam pendidikan adalah cara yang paling efektif dan berhasil dalam mempersiapkan anak dari segi akhlak, membentuk mental, dan sosialnya. Hal itu dikarenakan pendidik adalah panutan atau idola dalam pandangan anak dan contoh yang baik dimata anak. Anak akan mengikuti langkah pendidiknya, meniru akhlaknya, disadari atau tidak.

Bahkan, sebuah bentuk perkataan dan perbuatan pendidik akan terpatri dalam diri anak dan menjadi bagian dari persepsinya, diketahui maupun tidak. Disini keteladanan menjadi faktor yang sangat berpengaruh pada baik buruknya anak, jika pendidik adalah seorang yang jujur dan terpercaya, maka anakpun akan tumbuh dalam kejujuran dan sikap amanah. Namun, jika pendidik adalah seorang yang pendusta dan khianat maka anak juga akan tumbuh dalam kebiasaan dusta dan tidak bisa dipercaya. (Nashih, 2016:603) Maka kedua orang tua harus memfokuskan kepada pendidikan anak yang lebih besar. Hendaknya kedua orang tua mengerahkan segala daya dan upaya mereka untuk mendidik anak yang lebih besar karena saudara-saudaranya atau lingkungannya akan menjadikan dia sebagai teladan. 2) Mendidik dengan kebiasaan. Telah ditetapkan dalam syariat Islam bahwa anak semenjak lahir sudah diciptakan dalam keadaan bertauhid yang murni, agama yang lurus, dan iman kepada Allah. Sebagaimana firman Allah dalam Q.S Ar-Rum: 30

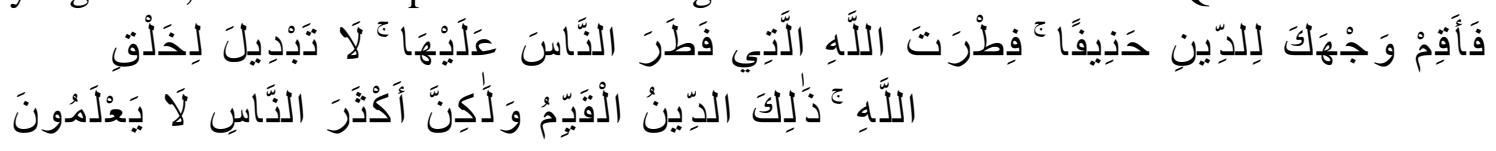


"Maka hadapkanlah wajahmu dengan lurus kepada agama Allah; (tetaplah atas) fitrah Allah yang telah menciptakan manusia menurut fitrah itu. Tidak ada perubahan pada fitrah Allah. (Itulah) agama yang lurus; tetapi kebanyakan manusia tidak mengetahui."

Mendidik dengan kebiasaan dan pendisiplinan merupakan faktor pendukung pendidikan yang paling baik dan efektif. Hal itu dikarenakan metode pendidikan tersebut bersandar pada kegiatan memperhatikan dan mengikuti, penyemangatan dan penakutan, dan bertolak dari pemberian bimbingan dan arahan. Sudah bisa dipastikan bahwa pendisiplinan anak sejak kecil adalah faktor yang memberikan hasil yang terbaik. Sebab, pendisiplinan ketika sudah dewasa sangatlah sulit, jika ingin hasil yang sempurna dan semestinya. Semoga Allah merahmati orang yang mengatakan: Pendidikan itu akan berhasil jika diberikan sejak kecil, dan sulit untuk berhasil ketika sudah dewasa, karena dahan yang kecil akan mudah dibentuk dan diluruskan, tidak seperti pohon kayu yang sudah tumbuh menjadi besar. (Nashih, 2016:639) 3) Mendidik dengan nasihat. Satu lagi metode pendidikan yang efektif dalam membentuk keimanan anak, akhlak, mental, dan sosialnya adalah metode mendidik dengan nasihat. Hal ini disebabkan, nasihat memiliki pengaruh yang sangat besar untuk membuat anak mengerti hakikat sesuatu dan memberinya kesadaran tentang prinsip-prinsip Islam. Sehingga tidak heran kalau AlQur'an menggunakan manhaj ini untuk mengajak bicara kepada setiap jiwa, serta mengulang-ulangnya pada banyak ayat yaitu firman Allah dalam Q.S Luqman: 13

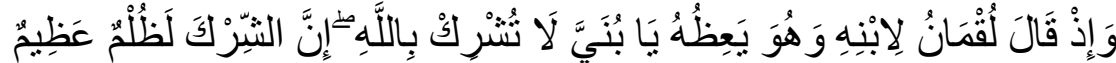

Artinya: "Dan (ingatlah) ketika Luqman berkata kepada anaknya, di waktu ia memberi pelajaran kepadanya: "Hai anakku, janganlah kamu mempersekutukan Allah, sesungguhnya mempersekutukan (Allah) adalah benar-benar kezaliman yang besar".

4) Mendidik dengan perhatian/pengawasan. Maksud dari pendidikan dengan perhatian adalah mengikuti perkembangan anak dan mengawasinya dalam pembentukan akidah, akhlak, mental dan sosialnya, begitu juga dengan terus mengecek keadaannya dalam pendidikan fisik dan intelektualnya. Islam dengan prinsip-prinsip yang holistik dan abadi mendorong para orang tua dan pendidik lainnya untuk selalu memperhatikan dan mengawasi anak-anak mereka di semua aspek kehidupan dan pendidikannya. Berikut ini nash yang mendorong untuk melakukan perhatian dan pengawasan terhadap anak-anak Allah berfirman:

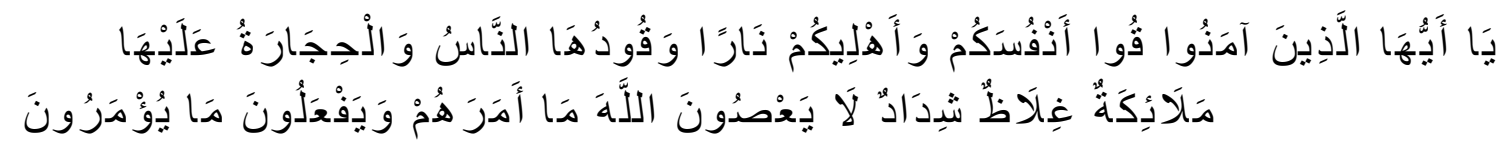

Artinya: "Hai orang-orang yang beriman, peliharalah dirimu dan keluargamu dari api neraka yang bahan bakarnya adalah manusia dan batu; penjaganya malaikatmalaikat yang kasar, keras, dan tidak mendurhakai Allah terhadap apa yang diperintahkan-Nya kepada mereka dan selalu mengerjakan apa yang diperintahkan." Q. S At-Tahrim : 6 
5) Mendidik dengan hukuman. Berikut ini cara yang diajarkan Islam dalam memberi hukuman kepada anak: (a) Bersikap lemah lembut, maka pengarahan ini haruslah diprioritaskan karena anak harus lebih diperhatikan dan dikasihi. (b) Memberi hukuman secara bertahap dari yang ringan sampai yang keras, artinya ketika semua usaha telah diberikan kepada anak sebelum memberikan alternatif terakhir, yaitu hukuman pukulan. (c) Menunjukkan kesalahan dengan mengarahkannya, dari hal ini bahwa Umar bin Abu Salamah berkata "ketika masih kecil aku berada dibawah pengasuhan Rasulullah SAW. tangan ku pernah tergerak kesana kemari dalam piring besar, maka Beliau berkata kepada ku:

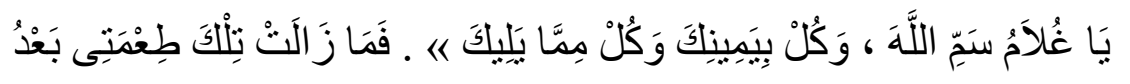

“Wahai Anakku, bacalah "bismilillah”, makanlah dengan tangan kananmu dan makanlah makanan yang ada di dekatmu." Maka seperti itulah gaya makanku setelah itu. (HR. Bukhari no. 5376 dan Muslim no. 2022) (Nashih, 2016:625-691)

Akhirnya apa pun alasannya, mendidik anak adalah tanggung jawab orang tua dalam keluarga. Itulah sebabnya sesibuk apa pun pekerjaan yang harus diselesaikan, meluangkan waktu demi pendidikan anak-anak adalah lebih baik.

\section{Relevansi Pola Asuh Orang Tua dengan Anak SMP}

Tidak seperti anak PAUD dan TK dengan tingkat ketergantungan dengan orang tua yang masih kuat. Betapa sedihnya seorang anak ketika mendengar dan melihat orang tuanya akan meninggalkannya dirumah karena sesuatu hal dalam jangka waktu tertentu. Dia sedih karena tidak membawa serta oleh orang tuanya. Tetapi, anak tidak akan pernah sedih ketika dia sendiri yang meninggalkan orang tuanya dirumah karena ingin berteman ke rumah tetangga dekat atau bermain-main bersama. Teman-teman sebayanya disepanjang jalan yang aman atau di pekarangan rumah disekitar rumah tetangganya.

Oleh karena itu, sesuai dengan posisi anak SMP berdasarkan periodisasi perkembangan, maka tipe pola asuh yang kemungkinan dapat digunakan oleh orang tua adalah demokratis. Dengan pendekatan pendidikan berupa pengalaman, pembiasaan, emosional, fungsional, keagamaan, dan rasional, maka metode pendidikannya adalah cerita, hiwar (dialog), hukuman dan ganjaran, simbolisme verbal, ibrah (mengambil pelajaran), mauzhah (peringatan), targhib (membuat senang), tarhib (membuat takut), hafalan, keteladanan, pembiasaan, dan memberi nasihat. (Bahri, 2014, hal. 97-98)

\section{Hubungan Pola Asuh Orang Tua dengan Motivasi Belajar}

Hubungan anak dengan orang tua, teman sebaya dan yang lainnya mempunyai dampak yang sangat besar pada kehidupan mereka. Interaksi mereka dengan guru, orang tua dan yang lainnya dapat sangat mempengaruhi motivasi mereka. Hubungan ini meliputi tentang : a) Karakteristik demografis. Dibandingkan orang tua yang kurang berpendidikan, orang tua yang berpendidikan lebih tinggi akan lebih percaya bahwa keterlibatan mereka dalam pendidikan anak merupakan hal yang penting. Ketika waktu 
dan energy orang tua sebagian besar dihabiskan oleh persoalan atau orang lain selain anak, motivasi anak dapat dirugikan. b) Praktik pengasuhan anak. Walaupun faktor demografis dapat mempengaruhi motivasi anak, faktor yang lebih penting adalah praktik pengasuhan anak oleh orang tuanya. Berikut ini beberapa praktik pengasuhan positif yang dapat meningkatkan motivasi anak : (1) Mengetahui kesalahan anak dengan cukup baik untuk memberikan tantangan dan dukungan dalam jumlah yang tepat. (2) Memberi iklim emosional positif yang memotivasi anak untuk menganut nilai dan tujuan orang lain. (3) Menjadi model perilaku yang memberi motivasi : bekerja keras dan gigih menghadapi tantangan. c) Pemberian pengalaman spesifik di rumah. Selain pengasuhan umum, orang tua dapat memberikan pengalaman spesifik di rumah untuk membantu anak menjadi lebih termotivasi. Membacakan buku untuk anak prasekolah dan memberi materi bacaan di rumah akan memberi efek positif pada motivasi membaca anak. (W.Santrock, 2011, hal. 224) Motivasi belajar berperan penting dalam proses pembelajaran dan keberhasilan proses belajar itu sendiri. Motivasi lebih banyak ditekankan pada individu siswa dengan harapan munculnya semangat untuk mengikuti proses pembelajaran. Motivasi yang dimiliki siswa akan menjadikan siswa memiliki semangat, disiplin, tanggung jawab, dan keseriusan mengikuti proses pembelajaran. Dengan kata lain, peran motivasi dalam proses pembelajaran siswa tidak lain sebagai sumber energi psikologis. Keberhasilan pendidikan sangat ditentukan oleh beberapa faktor pendukung, baik faktor internal maupun faktor eksternal. Kedua faktor tersebut sangat berpengaruh dalam keberhasilan tujuan pendidikan. Salah satu faktornya dari dalam keluarga. Orang tua merupakan motivator belajar bagi anaknya, sebab keluarga adalah pendidik pertama dan utama. Namun pada kenyataannya motivasi belajar yang dimiliki anak kurang. Oleh karena itu perlu diadakan penelitian tentang hubungan pola asuh orang tua terhadap motivasi belajar.

IV. HASIL PENELITIAN DAN PEMBAHASAN

1.) Pola Asuh Orangtua siswa kelas VIII SMP Bahrul Ulum Kota Bogor

Tabel IV.66

Pola Asuh orangtua siswa kelas VIII di SMP Bahrul Ulum Kota Bogor dengan menghitung angket sesuai kisi-kisi

\begin{tabular}{|l|l|l|}
\hline Pola Asuh Orang tua & Hasil & Persentase \\
\hline Otoriter & 561 & $23,37 \%$ \\
\hline Demokratis & 573 & $23,87 \%$ \\
\hline Permisif & 345 & $14,37 \%$ \\
\hline Jumlah & 1.479 & $100 \%$ \\
\hline
\end{tabular}


Berdasarkan Tabel di atas menunjukkan bahwa Pola Asuh orangtua terdiri dari tiga tipe yaitu (1.) Pola Asuh Otoriter dimana pola Asuh ini yaitu pola asuh yang memkasakan kehendak anak, tidak terbuka dengan pendapat anak, sangat sulit menerima saran dan terlalau percaya kepada diri sendiri. (2.) Pola Asuh Demokratis : Pola asuh demokratis ditandai dengan adanya pengakuan orangtua terhadap kemampuan anaknya sehingga anak diberi kesempatan untuk tidak selalu bergantung kepadanya. Orangtua memberi sedikit kebebasan kepada anak-anaknya untuk memilih apa saja yang terbaik bagi anak menurut anak itu sendiri, anak didengarkan pendapatnya, dilibatkan dalam pembicaraan terutama yang berkaitan dengan kehidupan anak itu sendiri. (3.) Pola Asuh Permisif Sifat pola asuh children centered yakni segala aturan dan ketetapan keluarga di tangan anak. Segala yang dilakukan oleh anak diperbolehkan oleh orang tua. Orang tua menuruti segala kemauan anak. Anak cenderung bertindak semena-mena, tanpa pengawasan orang tua. Didalam hasil penelitian ini mayoritas orangtua di smp bahrul ulum kota bogor menggunakan pola asuh demokratis dengan jumlah nilai $23,87 \%$. Pola asuh demokratis ditandai dengan adanya pengakuan orangtua terhadap kemampuan anaknya sehingga anak diberi kesempatan untuk tidak selalu bergantung kepadanya. Orangtua memberi sedikit kebebasan kepada anak-anaknya untuk memilih apa saja yang terbaik bagi anak menurut anak itu sendiri, anak didengarkan pendapatnya, dilibatkan dalam pembicaraan terutama yang berkaitan dengan kehidupan anak itu sendiri. Anak diberi kesempatan untuk mengembangkan kontrol intensitasnya sehingga sedikit-sedikit mereka lebih bertanggung jawab kepada dirinya sendiri.

2.) Hubungan Pola Asuh Orangtua dengan Motivasi Belajar siswa kelas VIII di SMP Bahrul Ulum Kota Bogor

Berdasarkan hasil analisa diatas dapat disimpulkan bahwa, nilai korelasi variabel X dan Y sebesar 0,755, jika dilihat dari tabel interprestasi nilai yang diperoleh yaitu 0,755 yang terletak antara 0,70-0,90. Dilihat dari interprestasi data termasuk korelasi Kuat.

Kemudian dengan melihat nilai tabel pada " $r$ " dengan nilai signifikansinya diperoleh " $r$ " tabel sebesar 0,432. Dengan demikian pada taraf signifikasi 5\% " $r$ " hitung $=0,755>$ dari " $r$ " tabel $=0,432$, berarti hipotesis alternatif $(\mathrm{Ha})$ diterima dan $(\mathrm{Ho})$ ditolak.

\section{SIMPULAN}

Berdasarkan hasil penelitian tentang Hubungan Pola Asuh Orangtua dengan Motivasi Belajar siswa kelas VIII di SMP Bahrul Ulum Kota Bogor, maka dapat ditarik kesimpulan sebagai berikut: 1) Pola Asuh orangtua di SMP Bahrul Ulum Kota Bogor menggunakan pola asuh demokratis dengan jumlah nilai 23,87\%. Pola Asuh demokrasi yaitu ditandai dengan adanya pengakuan orangtua terhadap kemampuan anaknya, memberikan kebebasan kepada anak. 2) Faktor yang mempengaruhi Pola Asuh orangtua ialah usia, status ekonomi keluarga, status pendidikan dan budaya. 3) Berdasarkan hasil analisa diatas dapat disimpulkan bahwa, nilai korelasi variabel X dan Y sebesar 0,755 , 
jika dilihat dari tabel interprestasi nilai yang diperoleh yaitu 0,755 yang terletak antara $0,70-0,90$. Dilihat dari interprestasi data termasuk korelasi Kuat. Kemudian dengan melihat nilai tabel pada " $r$ " dengan nilai signifikansinya diperoleh " $r$ " tabel sebesar 0,432. Dengan demikian pada taraf signifikasi 5\% "r" hitung $=0,755>$ dari " $r$ " tabel $=0,432$, berarti hipotesis alternatif ( $\mathrm{Ha}$ ) diterima dan (Ho) ditolak. Jadi terdapat hubungan yang signifikan antara Pola Asuh Orangtua dengan Motivasi Belajar Siswa kelas VIII di SMP Bahrul Ulum Kota Bogor.

\section{DAFTAR PUSTAKA}

Aenun Najibah, Nike Skripsi, (2017): "Hubungan Pola Asuh Orang Tua Dengan Hasil Belajar Siswa Kelas IV SDN Cempaka Putih 02 Tangerang Selatan”, (Jakarta: Universitas Islam Negeri Syarif Hidayatullah Jakarta).

Ali, Mohammad, (2016). Psikologi Remaja Perkembangan Peserta Didik. Bandung: PT Bumi Aksara.

Amin, Suci. (2018). Pola Asuh Orang Tua Dalam Motivasi Belajar Anak. Yogyakarta: Deepublish.

A.M, Sardiman. (2011). Interaksi Dan Motivasi Belajar Mengajar. Jakarta: Rajawali Press. cet 19.

Bahri Djamarah, Syaiful. (2014). Pola Asuh Orang Tua dan Komunikasi dalam Keluarga. Jakarta: Rineka Cipta.

Bisri, Mustafa. (2015). Psikologi Pendidikan. Yogyakarta: Penerbit Parama Ilmu.

Djamarah, Syaiful Bahri. (2011). Psikologi Belajar. cet.3. Jakarta: Rineka Cipta.

Karebet W, Muhammad. (2015) Motivaksi Metanoiac 5 Motivasi Plus 3 Aksi Menuju Muslim Terbaik. Bogor: Pustaka Motivaksi Metanoiac.

Lestari, Sri. (2014). Psikologi Keluarga. Jakarta: Kencana Prenadamedia Group.

Makarim, Chodidjah, (2019):"Hubungan Pola Asuh Orang tua Dengan Motivasi Belajar Siswa Kelas V Di MI TAHMIDIYAH”, Jurnal Pendidikan, Vol. 1 No. 2.

Makarim, Chodidjah, (2018):'Hubungan Metode Reward Dan Punshment Dengan Motivasi Belajar Bahasa Arab Di SMA Taman Islam Kabupaten Bogor”, Jurnal Pendidikan, Vol. 1 No.1.

Nashih 'Ulwan, 'Abdullah. (2016) Tarbiyatul Awlad Fil Islam Pendidikan Anak Dalam Islam. Depok: Palapa Alta Utama.

Rachman, M Fauzi. (2014). Islamic Teen Parenting. Jakarta: Penerbit Erlangga. 
Tanjung, Yanti. (2016). Menjadi Ibu Tangguh Meraih Kebanggaan Rasulullah SAW di Syurga. Bogor: Al-azhar Freshzone Publishing. cet 2.

Sugiyono. (2018). Metode Penelitian Pendidikan. Bandung: Alfabeta.

Sujarweni, Wiratna. (2019). Metode Penelitian. Yogyakarta: PustakaBaruPublishing.

Winarno (2013). Metode Penelitian Dalam Pendidikan Jasmani. Malang: Penerbit Universitas Negeri Malang (UM Press).

W. Santrock, John. (2011). Psikologi Pendidikan. Jakarta: Salemba Humanika. 